\title{
Phenotypic variability in a population of globe artichoke
}

\author{
Variabilidade fenotípica em uma população de alcachofra
}

\author{
Angélica Reolon da Costa ${ }^{\mathrm{I}^{*}}$ Simone Meredith Scheffer Basso ${ }^{\mathrm{I}}$ \\ Magali Ferrari GrandoI Vanina Pamela Cravero ${ }^{I I}$
}

\section{ABSTRACT}

The existence of variability is a prerequisite for genetic improvement in plants. Globe artichoke is a high nutritious vegetable with medical value, representing a profitable alternative for rural producers. This research was conducted with the aim of evaluating the phenotypic variability in a commercial cultivar of artichoke (Cynara cardunculus var. scolymus L) established from seeds. Field plants were assessed when primary head reached commercial stage. An amount of 21 quantitative and 5 multicategoric characters were assessed. The quantitative data were submitted to multivariate analysis. For quantitative characters the distance between individuals varied from 3.0 to 50.9, revealing high intrapopulation variability. The greater relative contribution characters for genetic divergence were the primary head fresh mass $(79.88 \%)$ and bottom fresh mass (8.43\%). This indicates the possibility of plant selection for head quality in this population. The clustering analysis through UPGMA method, based on quantitative characters, allowed the formation of five groups. For multicategoric traits, the similarity among individuals varied from $1.22 \%$ to $100 \%$. Within the existing population variability, it was possible to select plants with superior quantitative traits desirable for in natura consumption, as primary head fresh weight and length, bottom fresh mass, bract basis length and width, as well as non-quantitative traits as round head shape, absence of thorn and presence of violet color in the head.

Key words: Cynara cardunculus var. scolymus $L$, multivariated analysis, genetic breeding.

\section{RESUMO}

A existência de variabilidade é um pré-requisito para o melhoramento genético em plantas. A alcachofra é uma hortícola de alto valor nutritivo e medicinal, representando uma alternativa rentável para os produtores rurais. Este trabalho objetivou avaliar a variabilidade fenotípica de uma cultivar comercial de alcachofra (Cynara cardunculus var. scolymus L) estabelecida por sementes. As plantas foram cultivadas no campo e avaliadas quando o capítulo primário atingiu o estádio comercial. Foram avaliados 21 caracteres quantitativos e cinco multicategóricos, com posterior análise multivariada. Para os caracteres quantitativos, a distância entre os indivíduos variou de 3 a 50,9, revelando elevada variabilidade intrapopulacional. Os caracteres com maior contribuição relativa para divergência genética foram a massa fresca do capítulo primário $(79,88 \%) e$ massa fresca do fundo $(8,43)$, indicando a possibilidade de seleção de plantas com qualidade de capítulo nesta população. A análise de agrupamento pelo método UPGMA, com base nos caracteres quantitativos, permitiu a formação de cinco grupos. Para as variáveis multicategóricas, similaridade entre os indivíduos variou de $1.22 \%$ a $100 \%$. Foi possível selecionar indivíduos com características superiores quanto aos principais caracteres quantitativos desejáveis para o consumo in natura, como: massa fresca e comprimento do capítulo primário, massa fresca de fundo, comprimento e largura da base das brácteas, comprimento das brácteas externas, bem como características não quantitativas como capítulo de formato circular, ausência de espinhos e presença de cor violeta no capítulo.

Palavras-chave: Cynara cardunculus var. scolymus L, análise multivariada, melhoramento genético.

\section{INTRODUCTION}

Globe artichoke is an allogamous and diploid species, with a highly heterozygotic genetic structure (MAUROMICALE \& IERNA 2000; PAGNOTTA, 2010). It has nutritional and medicinal value, being considered a functional food (LOMBARDO et al., 2010; CECCARELLI et al.,

\footnotetext{
IPós-graduação em Agronomia, Faculdade de Agronomia e Medicina Veterinária (FAMV), Universidade de Passo Fundo (UPF), 99052-900, Passo Fundo, RS, Brasil. E-mail: angelreolon@ @otmail.com.*Autor para correspondência.

"Universidade Nacional de Rosario (UNR), Rosario, Santa Fé, Argentina.
} 
2010). The edible portion is the basis of the bracts and the bottom of the immature inflorescence, also called head. In addition, due to the great amount of biomass produced by the plant, it has been explored as energy source in the form of solid biofuel or bioethanol (IERNA \& MAUROMICALE, 2010).

In Brazil, the major globe artichoke producer is São Paulo state, with predominance of 'Roxa de São Roque' cultivar designated to in natura consumption. At Rio Grande do Sul state, this species got attention since 1994 with the development of Nobre cultivar, exclusively for industrial use (DONIDA, 2004). The University of Passo Fundo, in collaboration with the National University of Rosario, Argentina, began a globe artichoke breeding program aiming to develop material designated to the in natura consumption adapted to the climate conditions of south region to offer a profitable culture alternative for small farm properties in this region (REOLON-COSTA et al., 2012).

The knowledge of the existing variability among the available material is essential to genetic breeding, and allow the plant selection to be used as genitors in the breeding program (COINTRY et al., 1999) or to be in vitro cloned. Artichoke cultivars commercialized as seeds are originate mostly from open pollination populations, which results in high intrapopulation variability. This variability, even if it generates an undesirable lack of uniformity in the field, can be used in genetic breeding in intravarietal selection programs.

Plant selection aiming at genetic breeding requires analysis of a high number of characters (CRAVERO et al., 2002). In this sense, multivariate analysis is frequently employed, since it allows the interpretation and simultaneous evaluation of many characters as well as the use of existing interactions among a set of variables (CRUZ, 2006), as well as, and the estimation of genetic divergence between accesses.

The aim of this study was to evaluated the phenotypic variability in a population of an artichoke cultivar established by seeds in order to select materials with the desirable traits to be used in genetic breeding for in natura consumption.

\section{MATERIAL AND METHODS}

The experiment consisted of the evaluation of an artichoke population of 40 individuals in Passo Fundo, RS, Brazil. The region is located at $28^{\circ} 15^{\prime}$ $46^{\prime \prime} \mathrm{S}$ and $52^{\circ} 24^{\prime} 24$ " $\mathrm{W}$ and altitude of $687 \mathrm{~m}$. The climate is humid subtropical (Cfa) according to Köppen (MORENO, 1961).
Seeds of the Green Globe artichoke cultivar, obtained from the local market, were germinated in small pots containing commercial substrate with pine bark, vermiculite, liming material, and mineral fertilizers. The substrate had the following physical attributes: total porosity (0.832), pore space $(0.285)$, easily available water $(0.151)$ and buffering water (0.008). Four leaves seedlings were transplanted to field, with $1 \mathrm{~m}$ spacing and $60 \mathrm{~cm}$ between plants in line. Plantation occurred in April 2010 in soil prepared through sub soiling, liming (3.2t ha $\left.{ }^{-1}\right)$ and manure with NPK $\left(\mathrm{N}=180 \mathrm{~kg} \mathrm{ha}^{-1}\right.$, $\left.\mathrm{P}_{2} \mathrm{O}_{5}=80 \mathrm{~kg} \mathrm{ha}^{-1} ; \mathrm{KCl}=90 \mathrm{~kg} \mathrm{ha}^{-1}\right)$. The experimental design was completely randomized, with each individual consisting of a repetition. Evaluations were performed when heads reached commercial stage. The population was characterized according to artichoke descriptors (UPOV, 2001) taking in account 21 quantitative and 5 multicategoric characters.

Quantitative characters were: plant height (from the plant basis to top of primary head); plant diameter (one end to the other of the lower leaves); floral stem length (from the plant basis to the primary head insertion); floral stem diameter $(10 \mathrm{~cm}$ below the primary head insertion); number, length and width of the leaves; number of lateral buds formed after harvest; days of implementation to harvest; fresh mass, length and diameter of the primary head; external bract length; length, width and thickness of the bracts' edible portion (bract basis); thickness, fresh mass and diameter of the bottom; number of secondary heads per plant; bottom fresh mass/ primary head fresh mass ratio.

Multicategoric characters were: (1) primary head shape: round, elliptical, oval, triangular and large transverse elliptical; (2) head tip shape: pointed, round, flat and depressed; (3) external bracts tip shape: pointed, flat and emarginated; (4) external color of the bracts: green, violet-striped green, greenstriped violet, mainly violet and totally violet; and (5) anthocyanic pigmentation of the petiole: absent, mild, partial, strong and very strong.

Quantitative data were submitted to multivariate analysis through Euclidian distance average, and the relative contribution of the characters for genetic divergence by Singh method (1981). A dendrogram was generated through Unweighted Pair Group Method with Arithmetic Mean (UPGMA) method to analyze the relation among the individuals concerning the quantitative characters.

For the multicategoric data, the similarity analysis by coefficient (c) and hierarchic grouping by the Ward method were performed. All statistics analysis was performed by using Genes (CRUZ, 2006). 


\section{RESULTS AND DISCUSSION}

The plants within the population showed high phenotypic variability in relation to quantitative characters, seen by the amplitude of the characters (Table 1). Intra and interpopulation phenotypic variability in artichoke populations propagated by seeds have been found in studies conducted in the Mediterranean region (MAURO et al., 2009; PANDINO et al., 2011) and Argentina (COINTRY et al., 1999; CRAVERO et al., 2002). Variability in the population assessed may be attributable to the high rate or segregation observed in allogamous plants in sexual propagation and expresses the potential of this population in responding to the selection, allowing significant genetic gains. According to LANTERI et al. (2011), the artichoke's heterozygotic nature produces a great variety of phenotypes, mainly in cross-breeding results, and it can be exploited in genetic breeding when single plants with superior characters are to be selected.

Quantitative characters with greater relative contribution for phenotypic divergence were: primary head fresh mass (78.99\%) and bottom fresh mass $(8.43 \%)$. These characters are directly linked to the head's productivity and quality, indicating the possibility of selecting superior plants for in natura consumption in this evaluated population.
LANTERI et al. (2006) obtained similar results, where the primary head fresh mass trait was responsible by most of the variability of a population of cv. 'Spinoso Sardo'. For MAURO et al. (2009), this trait was also the one that better represented the variability observed among 24 artichoke accesses gathered in different regions of Sicily, Italy. These results indicated that the head's fresh mass could be used isolatedly for selection of a higher number of plants in order to reduce time and cost.

The Euclidian distance average $\left(\mathrm{D}^{2}\right)$ varied from 3.08 to 58.88 , showing the high phenotypic divergence. The dendrogram allowed the formation of five groups (Figure 1). Group I, composed by individuals $39,34,15,27,17,31,26$, presented higher mean values than the others for leaf length, main head diameter and bracts' base thickness. Group II, in which plants 4, 5, 1, 2 are found, had lower mean values for most characters assessed. In this group plants with greater days from implantation to harvest period were found (193 days), which is not a desirable character, considering that one of the goals of breeding is the search for earlier genotypes. The Group III was formed by plants with higher mean values than those of other groups for the characters external bracts' length, bottom fresh mass and bottom fresh mass/primary head fresh mass ratio, all

Table 1 - Width and relative contribution (RC) of quantitative characters for phenotypic diversity for forty individuals from a seed established artichoke cultivar.

\begin{tabular}{|c|c|c|c|}
\hline Character & Maximum & Minimum & $\mathrm{RC}(\%)$ \\
\hline Plant height (m) & 1.5 & 0.3 & 0.0011 \\
\hline Plant diameter $(\mathrm{m})$ & 1.3 & 0.48 & 0.0011 \\
\hline Floral stem lenght $(\mathrm{cm})$ & 1.8 & 0.3 & 0.0016 \\
\hline Floral stem diameter $(\mathrm{cm})$ & 2.3 & 1.0 & 0.0024 \\
\hline Number of the leaves & 42.0 & 8.0 & 1.161 \\
\hline Length of the leaves $(\mathrm{cm})$ & 0.98 & 0.42 & 0.0003 \\
\hline Width of the leaves $(\mathrm{cm})$ & 0.9 & 0.1 & 0.0007 \\
\hline Number of lateral buds & 6 & 0 & 0.1003 \\
\hline Days of implementation to harvest & 207.0 & 170.0 & 3.349 \\
\hline Primary head fresh mass $(\mathrm{g})$ & 376.54 & 158.84 & 79.88 \\
\hline Length of the primary head $(\mathrm{cm})$ & 13.5 & 6.5 & 0.0532 \\
\hline Diameter of the primary head $(\mathrm{cm})$ & 15.8 & 7.5 & 0.103 \\
\hline Length of the bract basis (mm) & 26.0 & 10.0 & 0.2906 \\
\hline Width of the bract basis (mm) & 57.76 & 20.35 & 0.9852 \\
\hline Thickness of the bract basis (mm) & 7.41 & 2.22 & 0.0377 \\
\hline External bract lenght $(\mathrm{mm})$ & 96.57 & 39.15 & 3.832 \\
\hline Thickness of the bottom (mm) & 14.55 & 7.51 & 0.0873 \\
\hline Bottom fresh mass $(\mathrm{g})$ & 115.88 & 35.89 & 8.425 \\
\hline Diameter of the bottom (mm) & 89.69 & 50.75 & 1.661 \\
\hline Number of the secundary heads & 3 & 0 & 0.0231 \\
\hline Bottom fresh weight/primary head fresh weight ratio $(\mathrm{g})$ & 0.44 & 0.14 & 0.0001 \\
\hline
\end{tabular}




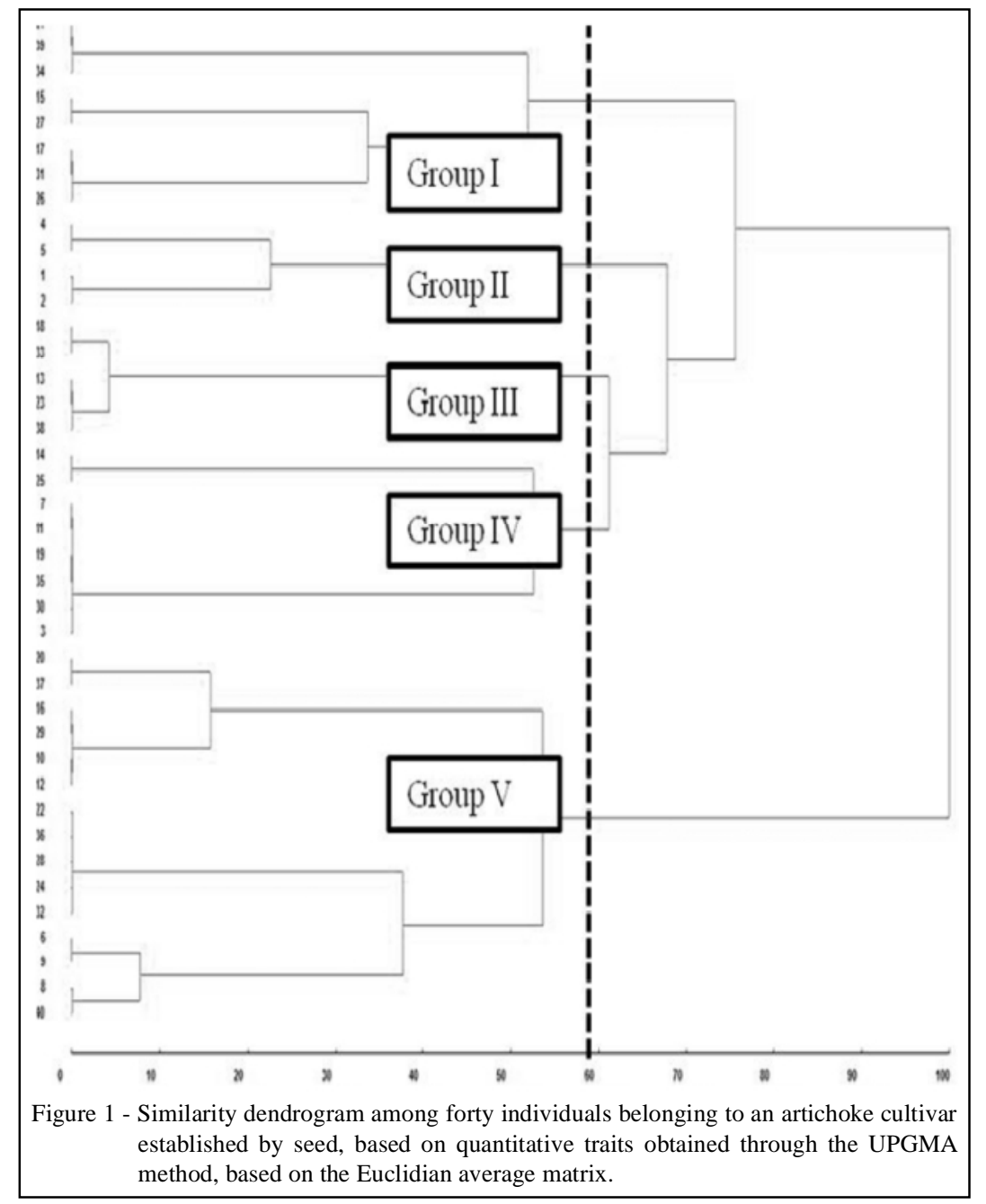

characters important for the selection of materials desirable for in natura consumption.

Group IV showed a similar behavior to the others in relation to characters of selective interest. Group V presented higher mean values than the other groups for primary head fresh mass and length, bottom diameter and number of secondary heads and others vegetative traits as plant height, plant diameter, floral peduncle length, number of leaves.

Therefore, in groups I, III and V plants with higher head quality and yield may be selected for inclusion in cross breeding blocks aiming to obtaini better phenotypes in the long term. Globe artichoke selection for in natura consumption is based on characters related to the dimension of the head, bracts' basis and bottom, i.e., the edible parts. Thus, approximately $50 \%$ of this population could be used in hybridization programs aiming to develop varieties or in vitro cloning, based on the evaluation of quantitative characters.
The assessment of multicategoric data is important for genetic divergence evaluation in segregating populations and can also be used as parameters in selection process aiming to genetic breeding. In this study, the similarity between pairs of individuals based on these traits varied from $1.22 \%$ to $100 \%$. More distant were plant 1 and 2, which differed mainly in primary head shape (1-round, 2-elliptical) and primary head tip shape (1-round, 2-flat).

For anthocyanic pigmentation of the petiole basis variability was minimal; only one plant (6) presented a strong pigmentation, the rest of the population presented weak anthocyanic pigmentation $(97.5 \%)$. The bracts' external coloration is of great importance, since in countries as France, Italy, Argentina, and Brazil, more heads that are violet are preferred. In this population, green striped-violetcoloration was observed in $40 \%$ of the plants, which can be part of the crossbreeding blocks aiming at accumulation of purple coloration genes. The other $60 \%$ plants presented green color (Table 2). 
The population presented high variability for the primary head tip shape, plants in the four classes described by UPOV (2001) being found. However, $65 \%$ of the assessed set showed heads with depressed tip, which is not desired in materials aimed at in natura consumption, since it enables water and microorganisms to enter, resulting in head quality diminution. The adequate shape for head tip (round) was found in $27.5 \%$ of the population.
In relation to bracts' tip shape, individuals were distributed between pointed, flat and emarginated, evidencing the population's variability for this character. Based on similarity matrix of multicategoric data, plants could be grouped in four clusters (Figure 2a). The multicategoric traits desirable for in natura consumption were head shape round, violet color and absence thorns. Based on this statement, these results indicate that, only the group IV can select plants with these three traits.

Table 2 - Multicategoric traits evaluated in a population of artichoke cultivar established by seeds and corresponding frequencies.

\begin{tabular}{|c|c|c|c|}
\hline Characters & Description & Individuals & Frequency $(\%)$ \\
\hline \multirow{4}{*}{ Primary head shape } & Round & $\begin{array}{l}1,5,6,7,8,9,10,11,20,23,24,25, \\
26,28,30,31,32,33,34,35,36,37, \\
38\end{array}$ & 57,5 \\
\hline & & & \\
\hline & Elliptical & $2,3,4,12,15,17,19,27,29,39,40$ & 27,5 \\
\hline & Oval & $13,14,16,18,21,22$ & 15 \\
\hline \multirow{2}{*}{ External color of the bracts } & Green & $\begin{array}{l}3,6,8,9,11,12,13,14,16,19,20,21, \\
22,14,25,27,28,30,32,34,36,37, \\
39,40\end{array}$ & 60 \\
\hline & Green striped violet & $\begin{array}{l}1,2,4,5,7,10,15,17,18,23,26,29 \\
31,33,35,38\end{array}$ & 40 \\
\hline \multirow{4}{*}{ Head tip shape } & Pointed & 15,17 & 5 \\
\hline & Round & $1,3,4,14,19,27,29,31,32,39,40$ & 27,5 \\
\hline & Flat & 2 & 2,5 \\
\hline & Depressed & $\begin{array}{l}5,6,7,8,9,10,11,12,13,16,18,20 \\
21,22,23,24,25,26,28,30,33,34, \\
35,36,37,38\end{array}$ & 65 \\
\hline \multirow[t]{3}{*}{ Anthocyanic pigmentation of the petiole } & Mild & $\begin{array}{l}1,2,3,4,5,7,8,9,10,11,12,13,14 \\
15,16,17,18,19,20,21,22,23,24 \\
25,26,27,28,29,30,31,32,33,34, \\
35,36,37,38,39,40\end{array}$ & 97,5 \\
\hline & Strong & 6 & 2,5 \\
\hline & Pointed & $1,2,3,4,5,15,19,27,29$ & 25 \\
\hline \multirow[t]{2}{*}{ External bracts tip shape } & Flat & $\begin{array}{l}40,6,7,8,9,10,11,12,13,14,16,20 \\
21,23,24,30,31,32,33,34,35,36 \\
37,38,39\end{array}$ & 60 \\
\hline & Emarginated & $17,18,22,25,26,28$ & 15 \\
\hline
\end{tabular}




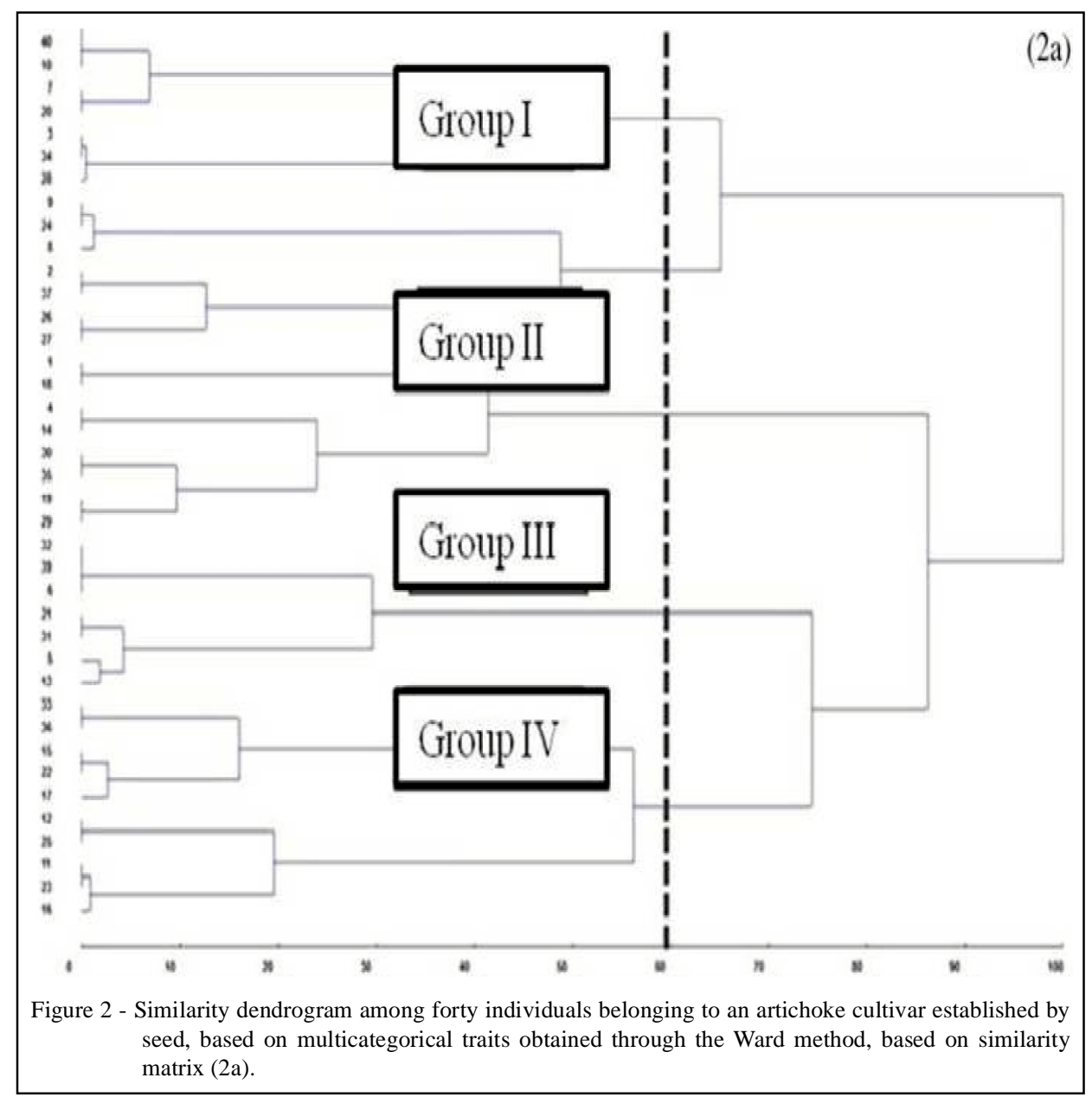

The results of this research evidence the existence of variability for multicategoric and quantitative characters in the population assessed. It is possible to select plants with the adequate biotype for in natura consumption, which may be used as genitors for breeding programs for species improvement. Plants presenting round head, round head tip, violet-striped green color, no thorns and no curvature of bract tip as well as higher values for primary head fresh mass, primary head length, bract basis length and width, external bract length, and bottom fresh mass could be identified and selected among the population assessed.

\section{CONCLUSION}

There is intrapopulation phenotypic variability in the green globe artichoke cultivar studied established by seeds in relation to quantitative and multicategorical traits, making it possible to select plants suitable to be used in artichoke breeding program.

\section{REFERENCES}

REOLON-COSTA, A. et al. Morphophysiological characterization in artichoke accessions aimed at selecting materials for in natura consumption. Acta Scientiarum Agronomy, v.43, n.4, p.431-437, Dec. 2012. Available from: <http://www.scielo.br/scielo.php?pid $=$ S180786212012000400010\&script=sci_arttext $>$. Accessed: Apr. 15, 2013. doi: 10.4025 /actasciagron.v34i4.14551.

CECCARELLI, N. et al. Globe artichoke as a functional food. Mediterranean Journal of Nutrition and Metabolism, v.3, n.3, p.197-201, Dec. 2010. Available from: <http://link.springer.com/ article/10.1007/s12349-010-0021-z>. Accessed: Apr. 12, 2013. doi: 10.1007/s12349-010-0021-z.

COINTRY,E.Eetal. Mejoramento genético delalcaucil. Horticultura Argentina, v.4, n.1, Ed. Online, 1999. Available from: <http://www. horticulturaar.com.ar/avancespop.php?idcontenido=19>. Accessed: Apr. 12, 2013.

CRAVERO, V.P. et al. Caracterización y selección de familias $\mathrm{S}_{1}$ de alcaucil a través de técnicas de análisis multivariado. Horticultura Brasileira, v.20, n.4. p.619-625, Dec. 2002. Available from: <http://www.scielo.br/scielo>. Accessed: Apr. 12, 2013. doi: 10.1590/S0102-05362002000400022.

CRUZ, C.D. Multivariate analysis and simulation. Viçosa: Universidade Federal de Viçosa, 2006. 175p.

Ciência Rural, v.44, n.11, nov, 2014. 
DONIDA, B.T. Produção e qualidade de sementes da alcachofra. 2004. 54f. Tese (Doutorado em Ciência e Tecnologia de Sementes) - Universidade Federal de Pelotas, RS.

UPOV. Guidelines for the conduct of tests for distinctness, uniformity and stability. Globe Artichoke (Cynara scolymus L). TG/183/3. Geneva, 2001. 28p. Available from: <http:// www.upov.int/edocs/mdocs/upov/en/tg/tg_184_2_proj>. Accessed: Apr. 15, 2013.

IERNA, A.; MAUROMICALE, G. Cynara cardunculus L. genotypes as a crop for energy purposes in a Mediterranean environment. Biomass and bioenergy, v.34, n.5, p.754-760, May, 2010. Available from: <http://www.sciencedirect.com/science/ article/pii/S096195341000019X>. Accessed: Apr. 15, 2013. doi: 10.1016/j.biombioe.2010.01.018

LANTERI, S. et al. A first linkage map of globe artichoke (Cynara cardunculus var. scolymus L.) based on AFLP, S-SAP, M-AFLP and microsatellite markers. Theoretical and Applied Genetics, v.112, n.8, p.1532-1542, May, 2006. Available from: <http://link springer.com/article/10.1007/s00122-006-0256-8>. Accessed: Apr. 15, 2013. doi: 10.1007/s00122-006-0256-8.

LANTERI, S. et al. Morphology and SSR fingerprinting of newly developed Cynara cardunculus genotypes exploitable as ornamentals. Euphytica, v.184, n.3, p.311-321, 2011. Available from: <http://link. springer.com/article/10.1007/s10681-011-0509-8>. Accessed: Apr. 15, 2013. doi: $10.1007 / \mathrm{s} 10681-011-0509-8$.

LOMBARDO, S. et al. Influence of genotype, harvest time and plant part on polyphenolic composition of globe artichoke [Cynara cardunculus L. var. scolymus (L.) Fiori]. Food Chemistry, v.119, n.3, p.1175-1181, Apr, 2010. Available from: <http://
www.sciencedirect.com/science/article/pii/S0308814609010267>. Accessed: Apr. 15, 2013. doi: 10.1016/j.foodchem.2009.08.033.

MAURO, R. et al. Genetic diversity of globe artichoke landraces from Sicilian sall-holdings: implications for evolution en domestication. Conservation Genetics, v.10, n.2, p.431-440, Apr, 2009. Available from: <http://link.springer.com/article/10.1007\% 2Fs10592-008-9621-2. Accessed: Apr. 15, 1013. doi: 10.1007/ s10592-008-9621-2

MAUROMICALE, G.; IERNA A. Speciale carciofo. Le attuali conoscenze: panorama varietale e miglioramento genetico del carciofo. L'Informatore Agrário, v.1, n.26, p.39-45, Jun. 2000 Available from: <http://www.informatoreagrario.it/>. Accessed: Apr. 15, 2013.

MORENO, J.A. Clima do Rio Grande do Sul. Porto Alegre: Secretaria da Agricultura, 1961.42p

PAGNOTTA, M.A. Genetic resources of Cynara spp. an AGR GEN RES European Project CYNARES. Kew Bulletin, v.65, n.4, p.555-560, Dec, 2010. Available from: <http://link.springer. com/article/10.1007\%2Fs12225-010-9238-8>. Accessed: Apr. 15, 2013. doi: 10.1007/s12225-010-9238-8.

PANDINO, G. et al. Chemical and morphological characteristics of new clones and commercial varieties of globe artichoke (Cynara cardunculus var. scolymus). Plant Foods Human Nutrition v.66, n.3, p.291-297, Sept, 2011. <http://www.ncbi.nlm.nih.gov/ pubmed/21792680>. Accessed: Apr. 15, 2013. doi: 10.1007/ s11130-011-0247-z.

SINGH, D. The relative importance of characters affecting genetic divergence. Indian Journal of Genetics and Plant Breeding, v.41, n.2, p.237-245, 1981. 